Marquette University

e-Publications@Marquette

Economics Faculty Research and Publications

Economics, Department of

1-1-1999

\title{
Postmodernism and Identity Conditions for Discourses
}

John B. Davis

Marquette University, john.davis@marquette.edu

Published version. "Postmodernism and Identity Conditions for Discourses," in What Do Economists Know? New Economics of Knowledge. Eds. Garnett, Robert F. London: Routledge, 1999: 155-168.

Publisher Link. (C) 1999 Routledge. Used with permission. 


\title{
10 Postmodermism and identity conditions for discourses
}

\author{
John 73. Davis
}

\begin{abstract}
Postmodcrnist thinking represcnts a collcction of critical pcrspcctives on

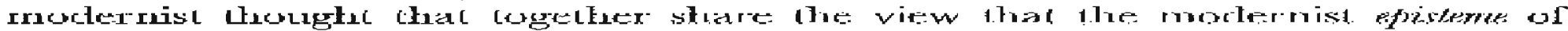

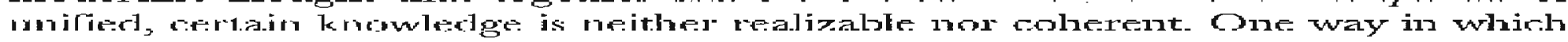
this is often expressed is in the form of a critique of essentialism, or the iclea that such classical cpistcmological notions as true, real, correct, logically necessary, and the like are required foundations for scicnce and understanding. Many postmodernists doubt that these notions are ulimalely viable, and argue that drey

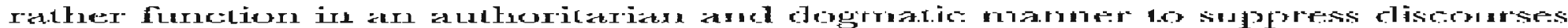
subversive of modern bureaucratic rationality. Essentialism, it is further argued, mistakcnly makcs our intellcctual idcal that of a complcte and systematic representation of the world. But intellectual activity on any candid reading, post-

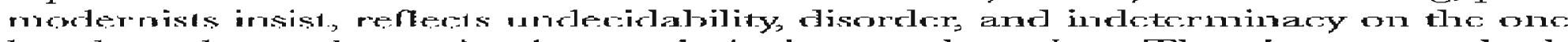
hand, and overdetermination arud rivalry on the wllex: That is, we are butly unable to ever really settle most things in life, and also unable to really narrow the range of competing discourses on virtually any given subject natter.

I think this critique valuatole and insightful in many respects. It has been well

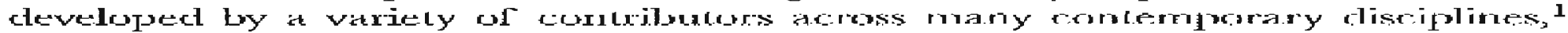
and is persisasive in a variety of ways to an increasing number of thinkers, including many trained in and still largely sympathetic to modernist tenets. In this chaptcr I am chicfly interested in the future trajectory of postmodernism, especially as the ellimts of its proponents arc dccrcasingly dincetcd toward the

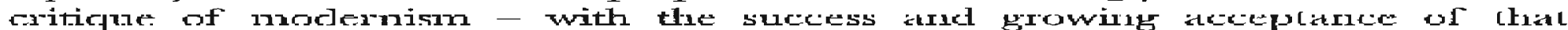

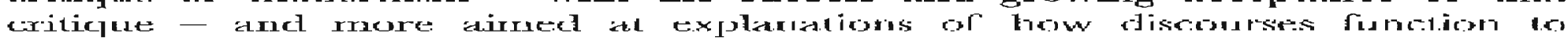
generate new thought. Surely one of the key perspectives postmodernism offers is the idca that thought is continuously dynamic and open ended rather than always converging toward a single set of static truths, the modernist ideal. Is it

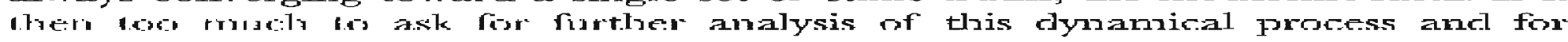
discussion of what this "un-systerm" involves? Sume frostruatermists mighl say that it is indeed too much, that we can only record moments of undecidability, disorder, and indeterminacy, and that cpistcrnological nihilism is an incritable and cren healthy mindset.

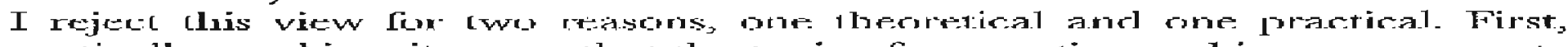
theoretically speaking, it seems that the topic of compering and incommemsurate
\end{abstract}


discourses, whether at a point in tine or across timc, is a suhject which we can coberently investigate in analyriring low people disagree with one anullus. This ropic is the chief theme of this chapter. Second, pretically spreaking it seems i:uperalive frow a progressinc political point of vicw that posmoderzists learn low (o) defroul opromess, pluralism, and tolerance in discoursc against reactionary forms of modernism. Doing this, huverver; inwolves both stuowing chearly and reasonably persiasively bow modernism can be morally arid politically unhealthy for socicry, and also showng that therc exists a handful of "essentials" underlying the non-anarchic play of competing discuursts lhat cxplain how a posmodern world is livable. This copic js a secundary theme of this chapter touched upon in the last section below.

My position might then be best put as holding that nibilism - or the view that we can only recurd muneuts of undecidability, disurder, and indelerminacy - is misquided, but that. what might. alternatively be termed frim ipleul relacivism - as will be set forth here - is meaningful and desirable. In what follows l try to investigatc conditions that might fulfill and tharackerizc a principled relativism, and then taln to louk cribically al posunudernist nihilisn. In the first section, a dilemma is first posed for masinumedernish discowse analysis that I suggest derives from its pass path of drwclopment as a oet. of ideas critical of modernism. In the second section, unc mcans of addressing this dilemma is sct out in terms of a discussion of whlat I term identity conditions for discuurses. In the thied scction, I turn to market. exchange models usert to elucidate interaction betwere.I discourses to give a specifically economic application of the idea of identity conditions for discourses, and then rccxaminc the original dilemma and its suggested solution frum dis nexv vantage point. Ir the fural section, I bricfly address the serondary theme of the chapter; argue in Fivesr of pritucipted relativism and against nihilism, and make a number of concluding remarks about political edrical issues that postmuderrusern ruises agaimst moder trism.

\section{A postmodernist non-comounication dilemma}

Ln the cullection of papcrs from the 1997 conference "Pluralism in Economies: Theory; Hisiory and Methodology" (Salanti and Screpanti 1996) in Bergarmo, Ttaly, Warren S'arnnels argues - correctly in my view - that alternative economic methodologies each possess their "own internal limitation and there is no singlc, unequivocal, conclusive mela-principle" upon which we can rely to choose among those methodologies (Sarnucls 1996: 67). That economic melthodologists have in the past sought. some "single, unequivocal, conclusive meita-prineiple." may be duc to a mistakcn vicw of what the application of philnsophical concepts to economics can accomplish A rnuder'nist view of the mattcr would have it that

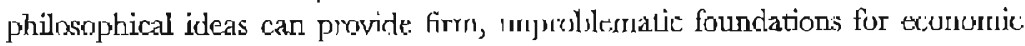
ones, and that philosophical ideas onee grasped are relatively uncontroversial ard convincing. A postruoderuist view of the matter might have it that philosoplical ideas are eomplex and problcmatical, and that their use is bellcr seen as shurbliand relerence to entive philosophical theories, each of whlich possess strcugths and wcakwesses relative to competing theories and like philosophical

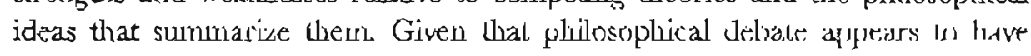
all the characieristics of an underidable exchange., it seems thar Samuels is correct in infening that prescriptivist economic methodologics in the Poppcrian-Lakalosian uadicion are snisguided in searching for "the principles of

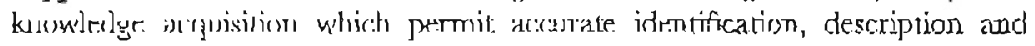
explanation of the subject" (p. 68).

A second, stronger claim Samuels makes is that "thorc is a tindanocntal, tautological relationship betwech the assumed principles of know'edge acquisilion and lle knowledge which is produced" ip. 68). Peirhaps "tautological" is 100 strong a term here, but it must at least he cluse to the scnse of Samuels' position, which is also cxpressed in tcrms of an idca riidcly accepted among postmodernists that one camner "slep out" of one's owli discorurse; that is, llere is something inherently contradictory about the idea that one might be detacherl from the way one sees things. 1 think that there is a dilemma here that results liom corjuinung this second proposition lhat knowledge is somethow tied to its eonditions of production to the proposition in the previous paragraph that inere

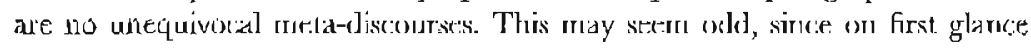
the twro propositions serm to be mucusally supporting. Is.t. me: then cxpand upon and reconstruct Samuels' case in an attcmpt to bring out what I bclicve to be the dilerruna ju question. In his view:

1 knowledge is tied to its conditions of pruduction; and

2 Lhare arc rnany distinct discourscs on any given subject (because the conditions of knowledge production are diverse).

From this it follows that:

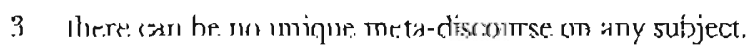

But trom this onc might also plansibly iwter that:

4 different discourses and their producers are non-communicating

This conclusion, however, surely poses a dilemma for postmodernim and its critiguc of moderuiser. On the onc hard, if different discourses and theiproducers are non-comminicaling: then no nne is in a position to confidently say that there is no single meta-discourse - and thus argue, that the pinjert of modernizrn is misconceived. In effect, undecidability across different discoursis underrijutses deferse of the (shared) clain that there is no single meta-discourse. On the other hand, if postmodernists agree that the modernist project is miseonceiwed, then explicitly shared ground does seem to exist herween discourses after all. 'l'his both roises doubts about the postmodernist crilique of esscrnlialist modernism, and suggests that knowledgc production may not be that closely ticd to its conditions of production. 
T thirk this slilcmina more difficult to discharge than mary pustusodernists aright supposc. In a scinse, it is one member of the class of the ancicnt onc-andthe-many or uniry-and-plurality paradoxes that first received especially clecer expression in comtredien with Platn's theory of forms. Plato's problem nas how instances of things dissimilar and yct rclated to one another eaeh fell under some universal category representing their shared quality. Here in its contemporary form the problem is mamifested in the dual demand that discourses be dissimilar in nature, yet also share a common, motivating moment that there is no meladiscourse subsuming them, the project of essenrialist modernism). The plurality xide, of there being diverse discourses is self-eviderk, but perhaps it sccins odd to say that different discourscs muse share a unity in something's non-cxigtence or in the absence of a mera-discourse. To say, however, twat differest discoulsess aje

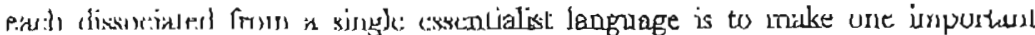
diand alsoul the origins and vature of cach. It is to gay that each posscsscs a specificity or particularity that derives from their like resistance to tornsiative

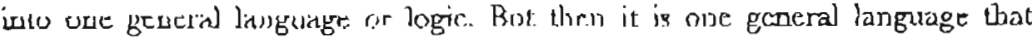
defines them all, if unly in a kyalive scusc. 'I he dilemma at hand, then, concerns the implicrtions of emphasizing either the plurality or the unity sides of posonodernism's combiuing a defense of diversily ancl a mumal discancing from modernist cssentialism.

Of course all dilemroas are dispellable to the extent that one is willing to embrare the consequences of taking one hom or the other of due dilesuma. For postmodernists, I singgest the process of futurc adjustment will require bccoming clearer about be idea that discourses appear non-communicating. Saying 山ral clifferent discourses are not hariked by a comrnon mota-discourse radkes discourses out to be non-communfating in only onc spceific scnsc. Nre there, then, other forms of linkage or communication between discourses compacible with this? And might these other forms of linkaye or communication presserve both the spccificity of different discourses in terirss of thicir scparace conditions of production and yct still support a critique of essentinlist modernism? Samuels would allow that there, are indeed forms of commumicatiun between discuursex bher (han jist tlas share. rejection of a single narta-descourse, sirice be does not embrace the conclusion of the reconstructed argument above that radical noncommunicarion is a necessary implication of discourses baving diverse conditions of preseluction. Iil sayjug low else discourses communicatc, chen, we might attempt to resolve the dilemma above by showing thar therc are linkages helween distincr discuurses that do not imply essentialist. calegories.

Note that an alteruative resolution of the dilerwed here would be sinply to cmbracc non-communication in a radical tashion, therehy giving up the search

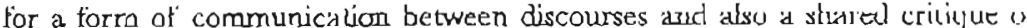

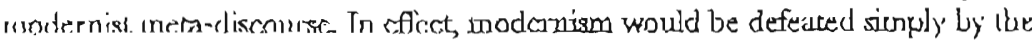
practice of indriduals always opcrating in terros of self-contrined discourses, miber chan by argument. 'This nihilist solution, however, seems an undesirable

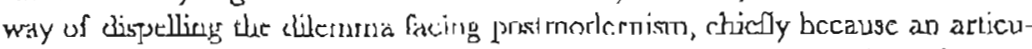
late critique of modernist essentialism is presumably important to the defense of diversity: Hut before developing this conclusion in the last section below; attention ought hrat be given in how ir might be thought: that the dilemma get forth atorve has come about historically with the emengence of postousdernisura.

My thesis here is that the dilemma lacing postmodernism has its origins in the way in which postmodernism historically developed as a critique of modernism. Suppose - to tell a slighlily apocryphial swry - that scholars struggled for many years with the classic, modernist correspondence problan 1cgarding how our representacions of the world relate to the world. These scholars' difficulcy tor maryy years was that they believed there io be one underlying reality, (hwugh itiey found themselves committod to competiog and often incommensurate ways of representing that reality. Finally after many years of fiustration and tiruitless

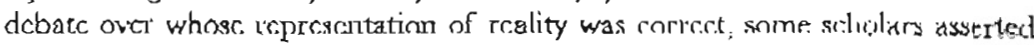
that the idca of a singlc, independent underlving reality must itse if be contradictory, because - reasonably enough - the idea of a single realicy is itself a

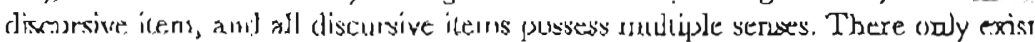

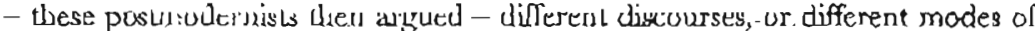
repregentanion. But now the dilemma emengex That it was originally thought Whal there exist genuinely disminct, alternative cliscourses depended ou the idred that, were there a single, unique underlying realit; then therc had to bc a single. unique mode of representation of that reality. That is, the idea of the distinct-

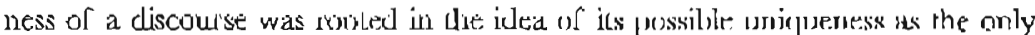
correct representation of a single reality. Yet if we now say that wo simpte, underlying reality exists, then the past basis lor saying that disconrses are genuinely

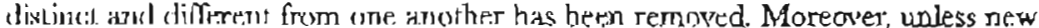
criteria lur explainum the idea ol dislincuess and difference are developed, it cannot be ruled out that discourses are more alike than different from one

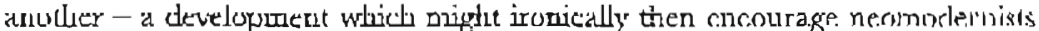
w argue that "different" discourses tend to, say, "convcrgc" on the "correct" representation of a singte, underlying reality. ${ }^{2}$

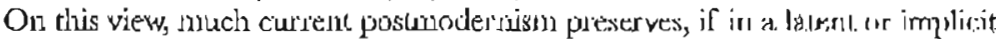
mannci; an important presupposition of morlcinism in that posimorlerrisure's concept of diflererace as uniqueness is an inadvertent inheritance from

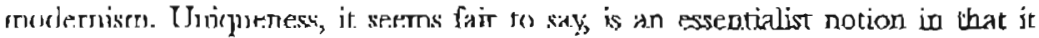
depeuds on the idea of a singte correspundence to a siugle reality. Tu say something is unique involves making a complete and comprehensive survey of the world, in order to say that one and one thing only ocmupies a certain place in that world. But postmudernists need not explain difference in ter'us of the idtea of uniqueress. There are other sways of explaining the concept of dificrence that postmodernism might adlopr: - ways which we wermlel hope would inabe speaking about diflesence ommpabihle with jointly dempring a single. meta-tiscnurce exicls, sustain the critiquc of modcrnism, and thus scrve to dispel the dilemma abor'e. Whar this suggests is that for postmorternist thinking to be successful ir needs to

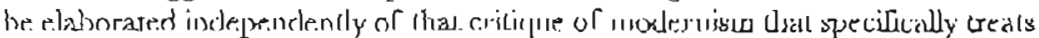
discourses as self-contained and non-eommunicaling. What is rather needed, more specifically, is an account of discourses' relative autonomy forn one. 
another, since an arcenunt of this sort would presurnably make a discoursc's distincluess a function of jis laleral juxlaposition to other discourses, rather than a function of its possession of the essentialist property of uniqueness. I now turn to how such an account might he alterupted.

\section{Identity conditions for discourses}

Ir essentialist reasoning tries to explain representation in terms of carrespondence to somcthing beynnd irgersentatiot, but-essentidist reasuning strives to remain within the ambit of representation, that is, it strives to account for distinct forms of representistion in terms of the whole of representation of in a holistie manncr. This involves explaining the relative autonomy of difficrent discourses by reference to the principles that account for the boundaries hetsvect discourges, where focusing on the dividing lines between different discourses makes their distinctress a function of their relation to one another. Holistic reagoning, that is, opcrates io terms of concrete wholes whose parts are from the outset the (internal) determoinations of chose wholes, $\Delta$ concept of dilference developed along thess: liues dues wot trade in the concept of unicuesiess, situce the wholc's parts -- herc different discourses orc differcut from onc another as related paris of une whule - or of discourse generally. Ditterence is understood immancntly, as it were, rather than absolutely

How specitically then, ahould the boundarics betwcen discourscs be conceptualized? When we speak of boundaries betwesu thinys we surnorise we are simultaneously concerned with thosc boundarics and the distinct and identifiable liiugx flueser boundaries permit us to distinguish. Further, to say that one has some distinct and identifiable itern is to say dhat onc cuuld elaborate identity conditions for that item which wmild allow us to distinguish and reidentify that ditig in a variery of settings and thrmugh change in the way we lalk abuer things. Iclentity conditions, that is, are criteria used for singling our, identifying, and relabeling thitysy we want to pay special atteration io, and reflect the implici ontologies of the language wc cmploy. To say that there are identity conditions for discourses, then, is wo say that theze: arre criteria for singling out, identifying and relabeling different discourses. The business of doing this, unorcover, both establishes the boundaries hetween discourses and determincs the rclative autonomy or idcntity that dilitereni discourses raay be sajd to possess.

Of course trying to say what makes onc discourse distinct from another is a herculean cask, since, in ctintrast to tangible things such as a rathle whose visual ontline and tactile qualities offer us obvious starting points, discourses are changing collections of retativity elusive, conr.cptual moves and practices that may well scem to lack any apparent identity whatsocver. ${ }^{4}$ Nonctheless, I suggest that the relalive sutonomy or identity of diecourses be, understond in terms of the functional roles played by two different types of concepts operaling in any given discnurse, where these two types of concepts arc distinguished according to the contributions they make to a cliscourse's unity ant divinuthess respectively. Fint, cvery discourse possesses concepts and notious which we may atgree are wentral to or conscitutive of that discourse. L.jke core concepts in Lakatnsian research programs, these concepts and notions may be thought key to that

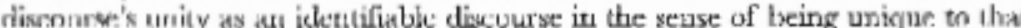
discourse. Second, every discourse also possesses concepts and notions which, thougl, mul constitutive of its unity ur spetific to that discourse, nonetheless play a rolc in that discourse. Unlike in the Lakatosian conception, these latter, non(x) misintive concepts may be regarded as boundary-markers, since, they are hoth lound in otler discourses and yet still play a role in the discourse under consideration. As opposed to explaining the unity of a discourse, thesc latter concepts may be understood as means by which we escablish the disturcteress $w^{5}$ a given discourse. In effect, they cnable us to pick out just where the disecurse in qucsticus comes into contact with other discourses.

Buth kinds of concepts, then, are necessary to cxplaining the rclative autnonmy or identity of a discourse in terms of its unity and discinctiveness from other discourses. An cxample may help clarify this conccption. In prost-Keynesian discourse the nodion of true uncertainty is regarded as a constitutive element in ecuilibrium umemployment arguments. In ncoclassical-syathesis Keysursians discourse the notion of rigid wages is regardicd as a constitutive clement in equilibrium unemployment anguments. Each coureet, then, contrithutes in the unity of these two Kcyncsian discourses. In contrast, the concept of an unemployinest. equilihrium, thnugh it is employed in hoth post-Keynesian and veoclassicalsynthesis Keynesian discourse, is constilutive of the unity of ueither argument. As a concept, it thus contributes to our picking out the boundary between the two fonns of argument. In effert, its differential anpowpriation in the two discourses tells us swere the two discourses both come into contact and yet remain dislinet.

Some, pcrhaps, will think this conception of a discourse with two different types of concepts cumbersome and unnecessary to explaining the relative autonomy or iclentity of discourses. Why not simply explain what makes discourses distinct and diflerent in terms of their constitutive notions alonc? The [nтlalen will pron:eeding in this manner is that if leavcs us with postmodernism's apples and oranges, non-communication problem. If a discourse's conscitutive concepts are specilic to that discourse alone, then in attending sniely to them we lacks a way of relating discourses to one another. However, in differentiating between it single discourse's consticutive and non-constitutive concepts we put ourselves in a position to cxplain that discourse's iclentity specifically as a relat ive autonomy, or as an autonomy relative to other discourses. 'Ihe key to this coracepron, it should now be aporerent, is in being able to kay tha both tyirs of concepes must operatc in any given discoursc. Not just a discourse's constitutive concepis, but also its associated penumbra of non-nonstitutive concepts musr be scen as ncccssary to the undcrstanding of that discourse.

Of corrse, saying that non-conslinutive concepts are as necessary to a discoursc as are ins consulutive courcipls sounk solul, but this is an enrirely reasonable view to adopt if discourse is understood holistically. Then, though constitutive conorpts are specific to individlual discourses, they sill teect to be 
162 Fohn B. Darns

understuod as operating in coujunction wilh a further apparatus of concepts that are not specific to that discourse. Holistic reasoning generally operates with complex tholes which may not be disasscrublud willuul destruying like whole,

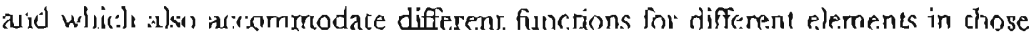
wholes. Here it is suggested that consticueive notions account for discursive unity and non-curstilulite nutions point to discursive boundasics that together cxplain the relative antonnmy or ideality of discourses.

Does this conccption, then, help us address the non-communication dilcnuna advanced above? The following seccion allerupts to answer this question in a positive way by considering a rather different set of grounds for operating in terms of the approach outlined. It has been suggested, for exarniple by Deirdre McCluskey (1994), that discourses and lluse: whos use themr rommunicate much in the way that economic actors intcract in marlects, and conscquently that we can divclup un understanding of discursiur intreartion or how disroureses conumusicate in terms of a model of market. exrhange. We thus torn to the market cxchange model of discursive intcraction in an cffort to detcrminc what more we might lcas's aboul corarcuurication fiom this perspective.

\section{Market exchange and discarsive interaction}

MLarkets rypically involve. decentralized exchaore between economic agents specialized in different types of produrtion wirhin all sverall clivision of labor. Nemilassical economic theory generally gives the idea of excbange a decidedfy moderaist interpretation by rcprescnting cconomic agents as atomistic individ-

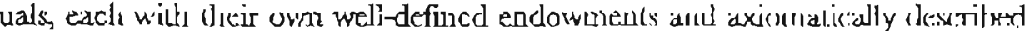
preferences, whose exchange with one another generates gains from trade for

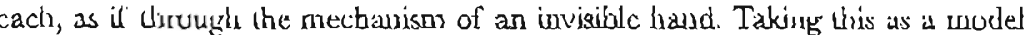
for the dulremation of rifferent discourses, a neorldssicist mighe then say that though individual discourse producers eaeh have their own linguistic cndowmeats and conccptual preferences, heir discursive tradc und intcraction with one another reflerts an underlying logic or meta-discourse that to neoclassical economists works much like how universal constraincd optimuzation results in a gernesal cquilibrium betweeco inklependent producers. Just is, that is, secmingly ven different economic agents' trade with one another reflects one, underlying meta-discourse of bade that may be vaplurcel in sets of equitionas whose joint solution can be proven to exist, so that discmurses and their pmducers generally: on the traditions neoclassical model of market cxchangc, preswanbly share a curnulort mela-language or decp gramnar that makes comuunicaljon possible.

There are ways, horvever, to represent masker exchange as a model for discursive interaction that bypass the modernist ficarures of the neodassical accomal.

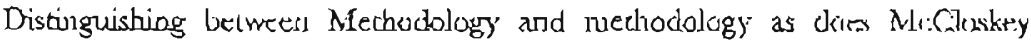
(1994), we might say that discursive trade and interaction are not guided by a.n underlving logic or unclarlistourse but rether by multiple, evolving norins of conversatiou, "Therre is ... ror Methodology of economies ... only sustained verbal ard written incratiotion which defics abstract characterization, bccausc it

is imberent is late uridvoidably cuncrete relatiouskips obtaining between ernnomists" (Thatis 1990: 83). One reason to think this is that there is growing cridence thar economic agrents are not appropriately all modeled as individual,

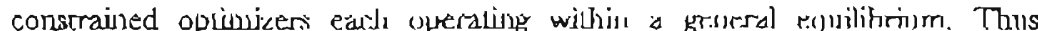
prychologists have argued that human derision making niten does not satisfy the ayjomatic requirements of neoclassical thcory (cf. Thaler 1992), elhucists buve argued that indivicluals in markets often act from non-self-regarding, non-utilityenhancing, alouistic motives (e.g., Sen 1987), feminists have argued that powicr and parriarchy socially detennine the actions of wornen and men ficrber and Nelson 1993; and a range of heterodox economists see class, corporate poiver, culturc, social values, and a variaty of other explanations of behavior as bciug centrally involved in markels. None of lhese types of explanations are ncady suited to producing a modernest determinaey in the analysas of exchange in markets. 'l his strongly suggests that thcic arc good icascuss to belicve thill market

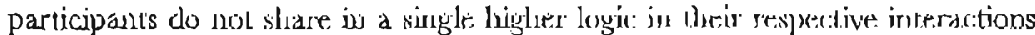
with one another, and that we accordingly ought to attend-mone carctult; to different and changing forms of hchavior in narkct activicy. But if this is the case, then modeling discursive materaction as market exchange in terms of a formal symmetry of behaviors explicable in terms of a single mathomatics is entirty misguided. Rather, we should setk to explain the changing and often incompatible means by which very diffenent discursive agents negotiate

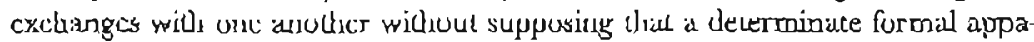

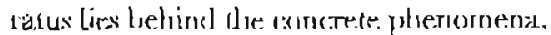

Before considering hnew to go abontt this, however, we should note one very tangiblc advantage to using conccpts of markct cxchange to model discutsive interacoion. Saying that. indiriduals and discourses interact with one another much in the way that nuarket participants cngagc in crchange iroplies that sunze how discourses do succeed in communicating despite their origins in verry different conditions of production. Indeed, this conclusion is only reintinsced should we agtee that, contrary to much traditional thinking in ncoclassical ecronmics, there is no single meta-logic underlying redl-world market exchange. Then the fact that exchange does occur tells us that economic agents' particu-

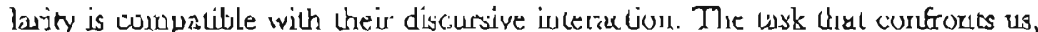
then, is to explain just hour discursive particularicy is compacible with discursive intcraction understood as a kind of trade. An example applying the discourse analysis deteloped in the lasl section is suggestive.

Consider household exchange. between women and men in ahusive domestic violence refationshipg whace trade is treated as a for of of discursive inccration. On the view above, consticutive and non-onstitutive concepts characrerize the respecive discourses of women and men. How may we understand doracsic violence in marriages involving production speciatization and cxchnngc in ecrms of these nio kinds of concepts? Farmer and Tiefenthaler (1997) explain domestic violence in non-cooperative relationships where men derive utility from violence agatisst wornen, and worren derive ulility from real income received in exchangc. While the Farmer-'I ietenthaler anclysis explains the behavior of both 
women and men formally in terms of a single mathematics of constrained oplimicalion, we may dejart from and veinterpret their wality analysis to dillerentiate two distincl discourses in the dillerent arguneuts of women anl men's 17spective ublity tunctions. Only men, not women, derive ulifity from violence perpetrated agaisis wimen. Thus we. Iridy kxy Hat constitutive of the discourse of men cngaged in spousal aljuse is as set of conccply Ujad lit: welf-testeem to spousal abuse In contrast; womm may he said to uaderstand theid statur ay a

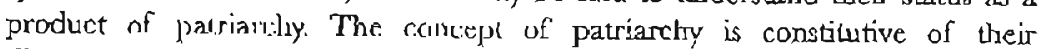
discoursc. Thus though formally cach may be said tn liave. milicy fumctions, a more concrete analysis of thcir preferences gives us a basis fur silying that thcy cach pnisress a wore of specific: concrepts that make their discourses highly incommensurate with one anothar.

At the saase time, however, there are nor-conslitutive concepts in the discourse of cach whiclu are specific to neither discourse, bul which work together with cach one's cons(itutive concepls. IIere we may iefer lo moncopts which cach possesses that concern such things as the valuc of family ancl hume, the importaster of joint income, rultural expectations about married life, desire for companionslaip, asld so on ${ }^{4}$ As nun-constitutive: lhis lintier set of concepte operates diflereotly for Homan and men according to how they respectively integrate them logether with llouse cuncepts constitutive of their two respccive discourses. Thus mones alay underscond the sarrifices to abuse they ratake personalfy for family and children as part and purel of living in a palriartial soriciely. Altrmatively, abusive and violenr. men may see family and children as further aspects of thicir owil selli-nagnificatirm. Each conseguently shares a scr of (non-constitutive) concepts, but those conecpts function difforntly for eatis in two disuincl sije:nirses. Thus their two discourses are relatively autonomous and identifiablc by baving hoth a disliucl cure of concepts and hy sharing conrepts that mask out che points ol concact or boundarics with one ariulher

Thr. Fixmer-Tiefenthaler analysis also explains the breakdown of abusive rclationships and the tertuination of exrhange hetween the women and men involved in them in terms of a threshold or threal print at which wowerd crise. to accepl the marriage's cumbination ol real-income tranzfers and spousal abuse. In our framcwork, the respective discoli'ses of women and men cease to communicate. Wc might say, using the fia'mes-Tiefentholer cullusiois on wormeo's shedrers aull support necurorks as a. form of real inconc, that in thesc circumstances wnilrin's discourse dimps thuse ann-ronsrintive concepts shared with men regarding family and homc, and adds ncw nom-ronsfiulive cuncepts shared will cuther abuse victims regarding personal security and non-patriarchal family

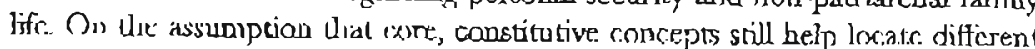

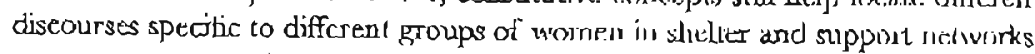
say, concepts regarding class, education, and social advantages, theu discursivc intelacion reenur.ryts when different women's discourses differendy integrale their respective core constitutive concepls with their slaterd, non-constitutive conrepts, which mark out points of contact and boundarics between rclativcly autonerrusu dismurses within sheller and support networks.
Using a markct modcl of discoursc, thit1, discursive interaclion, lilie economic exchange, is periodic, interrupted, and shifing. Indeed, we may firther complirate the pictiate above. in two ways. First, on a posmondern siew of discourse as a form of exchange, discursive parties presumably (rade at trany siles; in the piocess simulancoualy rcconstituting themselves in a variery of ways as they

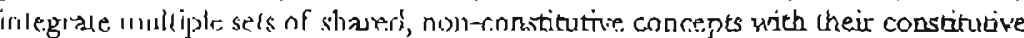

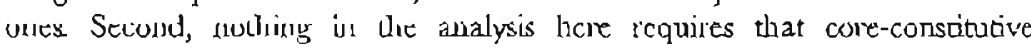
concepts be unchanging; "lo the cxtcnt that wc are successful in cliaracterizing concepts specific ro a ctiscourse, conblitulive concephx prissess a chegres of slabilily: But clearly on lite exchange model of discursive interaction the abundance of contacts between discourses argucs for change in corc, constitutive

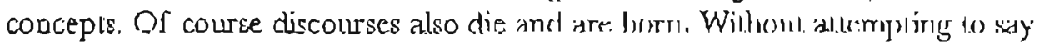
herw changing interaction between discuurses in lerws of nun-consilutive concepts impacts on core concepts, we may simply say that the continual resitirur of disclusive interaction contributes to the elimination, creation, and transformation of discourses.

Thus there is considerable undecidability and indeterminacy in the framewurk reveloped herc to explain the relarive autnnnmy and identity of discourses

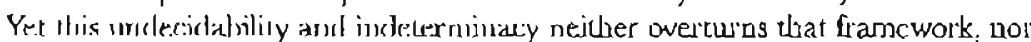
leaves us with the non-communication dilcmma sct out above. Discourscs do

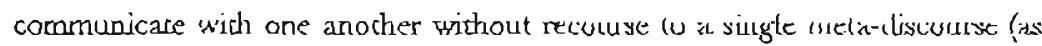
individuals may interace in inarkets withont a resclakeinl formalisml), and vid. (jiscourscs may still be understood in terms of their distincl conditions of pmduction. Does this framework then, offer solid grounds for sustaining the

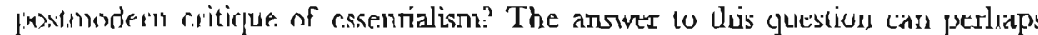
best be given by comparing nihilism and relativism.

\section{Nihilissm, relativism, and the politics of postmodernism}

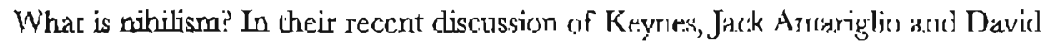
Kuccio (I y45) takc Keynes' latc crnphasis on animal spirirs and uncertainty as an impeneabable barrier to calculative rationalily, and thus as an important postmesle.m e.lement in Keymes: thinking that helped introduce indeterminacy and undecidiljilily inte cunteruporary economic discourse. "I hey sec this as part of "a progressive slide mto nihilism" or Kryncs' part, bist argule thar. Krynes should

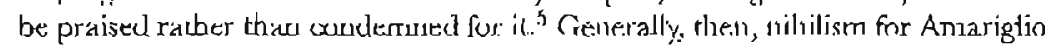
and Ruccio and many postrnodernists is the vicw that discoursc is always incomplete: fragnented, and lader with indeterminacy. Embrecing nihilism thus

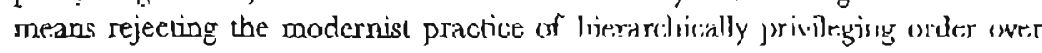
dismeder, and wrongizing that attcmpts to "domesticate" uncertaialy are ultimately doomed to lial (also cl. Amariglio and Ruccio 1994).

This view would seem to imply that the discursive world cannot be made ip of dillereut, relatively self-containcd discourses, sunce to supposc this would be to posit some degrec of order over the disonder. Wibile Amariglio and Ruccio, as 
wcll as other pastmodernists who have written on ninilism, are more disposed toward the ietrid of dialog betwreen distinct, relacively self-contained discourses than the characierization of nitidism here would seens to suggegl (cl. Amariglio, Resuick, and Woll 1990; Ruciiv 1991; it is nonetheless insmuctive to corsider the consequences of nihilism lor the dilemma set forth in this chapter. Thus, scre uncertaintr and undecidability pervasive, it wolda folluw thal commurication and shamel undcrstanding between different postonodernist discourses

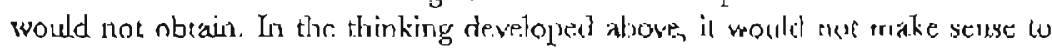
say that these discourses shared a set of non-constintive concepts persining to a shared critiquo of wodcrsisses. In effect, un a tubilist view diversily stwaraps common ground But this jars with the evinent common grolund postmodernist discoulses share against modernisus.

There is a related consequence of embracing pervasive indeterminacy and undecidability. If disorder always conquers order; so that one can never hope to "clomesticate" spheres of tiscnurse. then difference dominates coberence absolutely. Radical uncertainty understood in this way then, inverts the completeness and finality sought in modernist rationality, since it still rlaims that there is one, single reality (characterized now in tcrms of universal fragmentation and omnipresent disorder), and still proposes to work in tenms of a singte. langnage. (that of indeterminacy and undecidability). Nihilisn, as argucel above is counce-

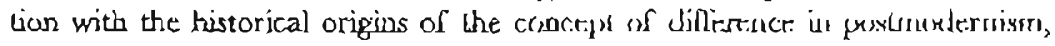
simply works in terms of an alfcrnative sct of absolutes. In cftcct, it opposes core

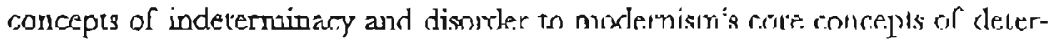
minacy and order, but sharcs non-constirutivc, boundary conccpts of a single language and a single reality. Postmodernism understoon in these lerms is a form of discursive interaction with modernism, rather than an internally differcntated whole of postrnodernist voices relatively autonomous chiefly in respect to one another:

I liurik the latter form of postnodernism - that is, we that differentiales jostmodernist vorices relative to one another rather than relative to moder'nism - is the prefered oure. And in place of nihilism, I also recommend postnodernists adopt what was earlier labeled a principlcd rclativism On this conccption particular discourses possess temporaty and relative stability that conalsles their romparative investigation, though nothing in this suggests they can be arranged in illy kind of tieranchical order. Whac can irstcad be achicved is a cocussdiscourse type of investigation that builds an arcount of differences between discourses in Lerris of diem differential appropriarion (via their respective coustihrive concepis) of shared non-consitutive concepts. Generalty, then, comnumicaviun is relative lo the ctiveuurse in which one operates, just as Samuels argued. Pur our ability to explain the relative character of discourse turns on the principles involved in reading across discourscs berc tiod up with the treatment of constintive and non-constitutive concepts. Thus a principled relativism offer's postmodcrnism a means of preserving an emphasis on undecidabilicy and indctermirlaky while also insuring a form of comrnunication between different postrisodcrsisc approactes.
Nihiljsm, in contrast, suffers at least two important vulnerabilities as a postmodersist approach. In the first place, discursive crehangc and interaction

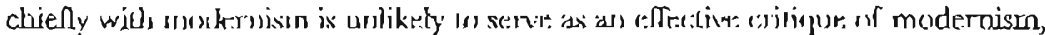
since - on the model of discursive interaction adopted hete - the core concepts

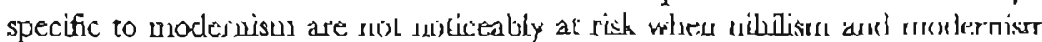
discursively interact over shared cornmitonent to a single (though different for cach) languagc and rcality. No doubt conrinced moderuists, perhaps ucotuulemista, will say that gaps, discrepancics: undecidable moments, and so on are just a part of an incxirable: progecss boward knowledge. In the seconnd place focusing on the redationship betye.en prostondemiem and modernism retracts from attention to muluple interactions among multiple discowycx. Bul allc:tlior to the latter is not only important for understanding the dynamics of discourses - what njglit be thought the positive project in postmodernism - but also for simply demonstrating that thcre exists no singlc, meta-discourse.

This last point is a valuablc onc to conclude upon. Onc dimcresion of postmodernism that especially deserves emaphasis is the form-of its political progressiveness. While historically Enlightenment modemism was politically progrcssive in defending rights of individuais agrimst theocrado, pown, torlay pustmudervism is pulitically progressive in defending colerance and openness aydinst modern bureaucratic racionality. Indeed, the defense of diversity and pluralism appears to be the chief practical consequence of postmodernist discourse. That program, in its many aspecty and dimensinns, seems wrill served by exhibition and analysis of the variety of forms of discourse and thcir modcs of discursive inceraction. The aroumenr in this chapter atteupts to map ont some of this dymamic.

\section{Acknowledgments}

Helpfiul comments on previous versions of this essay were provided by Zohreh Emami, Rub Gurnell, Wade Ilands, Tuny Lavion, artd Warren Samuels.

\section{Notes}

1 For economics, in particular, see the collection of papers in Samuels (1990;:

i) Hausman's ( (Y'S'L) treabment of ecoporaics as an inexact science mighl be undergtood in these leriux.

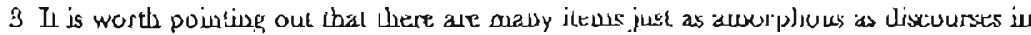
tegard 10 idenciry that we curtomarily ueat at distine and seidentivable. Fivin the social world, for example, theje are oue's uoral obligations, a certain group's cutployment prospects, the legal rights to those accosed of crimes, polícicil platorms ment prospects, the legal rights to those accosed of crimes, polivicil platorms,
custurns, and so un, seemingly in a lise almust without limit. Indeerd, most of the "Lhiongs" we are inlerested in social life lave sather iwtractable idencicy condinons That we nonctbeless deal with them regularly as dirtinct and reideatifablc implics we have coherent means of doing so.

4 Note that all these iterns may be framed in utiling rerms.

is Condtingson (1982) initiated the nihilism cririque of Keynnex and Shackle, but spoke of it pejorabively? 


\section{Eibliograping}

Amaxiglio, I. and Ruccio, D. (1904) "Postmodcrmism, Mampism, and the Critique of

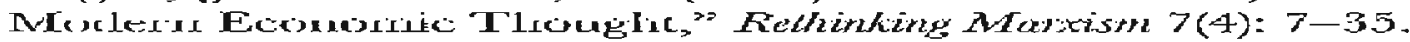

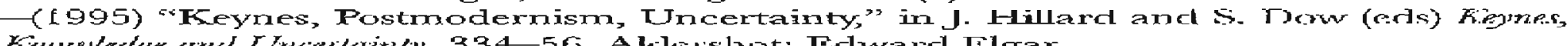

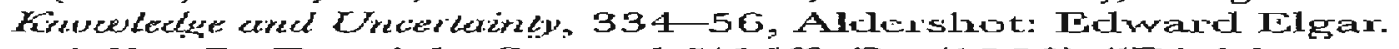

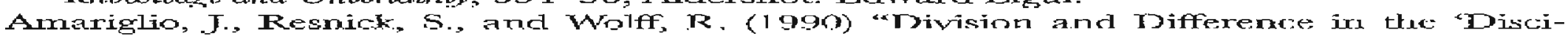
pline" of Ecomomics," Cricical Inquiry 17 (Avtuma): 108 37.

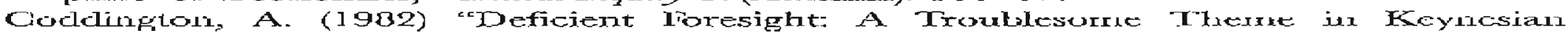
Fcomonnics," Americkn ficonomic Reziezes $72(3)=480-7$.

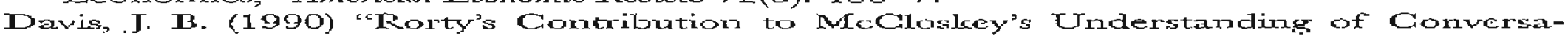

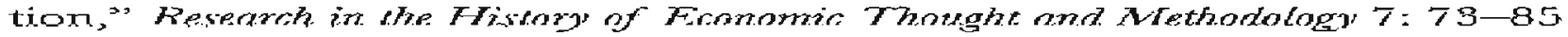

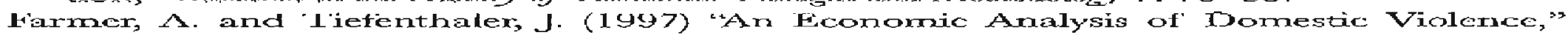
Revieve of Sucial Ficonon? $55(3)=337-58$.

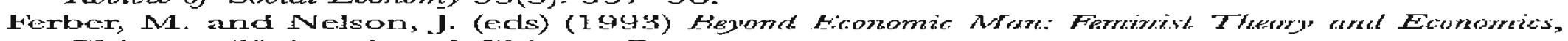
Chicaga: University of Chicago Pressi.

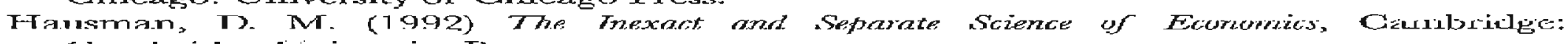
ciamalacidge t_miversity Tress.

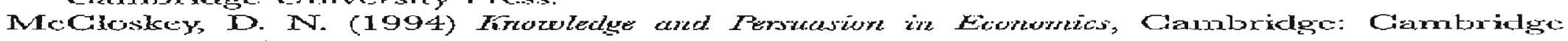
L miversity Fress.

Ruccio, D. (1991) "Postmodernism and Economics," fournal of Post Keynesian Liconamias $13($ Simmerme: $49.5-510$

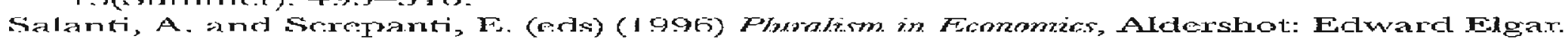

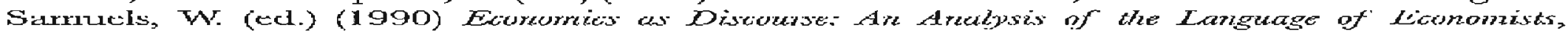
Foston: Isluwer.

(1996) "The Case For Methodological Pluralism," in A. Salanti and E. Screpinti (ens)

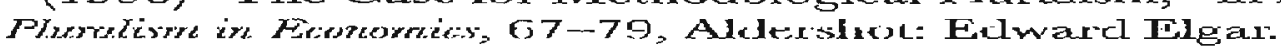

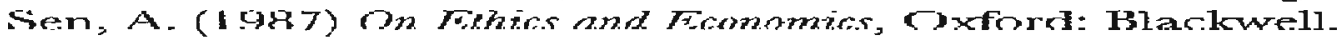

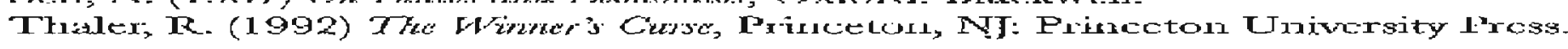

